\title{
The Implementation of Demonstration Method to Increase Learning Interest and Outcomes of the Second Grader As-Shakireen School, Thailand
}

\author{
Reta Kusuma Wardani ${ }^{1}$, Kamalia Fikri ${ }^{2}$, Ulyanada ${ }^{3}$ \\ ${ }^{1}$ Student of Biology Education, Mathematics and Science Education Departement, Faculty of Teacher \\ Training and Education, University of Jember \\ retakusuma97@gmail.com \\ ${ }^{2}$ Lecturer of Biology Education, Mathematics and Science Education Departement, Faculty of Teacher \\ Training and Education, University of Jember \\ kamalia.fkip@unej.ac.id \\ ${ }^{3}$ English Teacher of As-Shakireen school, Thailand
}

\begin{abstract}
This study aimed to increase the interest and learning outcomes of English through Demonstration Method in class II students of As-Shakireen Primary School, Thailand. This research was a classroom action research. Data collection techniques were carried out by means of observation, interest scale, and tests. Data analysis techniques were carried out by means of qualitative and quantitative descriptive. Increased interest and English learning outcomes with Demonstration methods carried out from pre-cycle activities, cycle 1 consisting of stages of planning, acting, observation, and reflection. Based on the results of data analysis, it showed the scale of student interest from pre-cycle to cycle with the use of demonstration method has increased. While student learning outcomes also experience an increase as indicated by the average value of students and the average students who exceed the minimum criteria. So that the demonstration method implemented can increase the interest and learning outcomes of class II students in English subjects at As-Shakireen primary school.
\end{abstract}

Keywords: demonstration method, learning interest, learning outcomes

\section{INTRODUCTION}

Learning is a business process that is carried out by a person to obtain a new change in behavior as a whole, as a result of his experience sen-envy in interaction with the environment (Slameto, 2010). Learning activities are a process of education in schools. This means that the success or failure of the achievement of educational goals depends a lot on how the achievement of educational taxonomy experienced by students that include cognitive, affective and mechanical skill aspects (Siagian, 2015). Based on the prerequisites needed for learning, in a learning every student must strive to be active, active learning is meant here by experiencing themselves, practicing, and doing activities so that their thinking, emotional, and skills, as well as learning activities, are increasing (Riswani \& Widayati, 2015).

Efforts to improve the quality of education today continue to be developed by involving the participation of students to be active in the teaching and learning process.
Learning will be more meaningful for students when students are included in each learning activity directly, with teachers as mentors and facilitators, so that the learning system runs in two directions and is not monotonous. The role of the teacher here is to arouse students' interest and raise student activity to participate in learning and teaching activities and ask questions for everything that is not understood in the learning process. One feature that indicates that students participate actively in a learning is to ask. Active students during the learning process are one indicator of students' desire or motivation to learn.

From the results of observations made at As-Shakireen School during the English learning process that was taking place in the classroom, there were still many students who did not pay attention to the teacher's explanation. Some students prefer to scribble on their notebooks, some are daydreaming and do not concentrate during the lesson. Students tend to do other

Bioedukasi Vol. XVI. No. 2 Oktober 2018

Received 12 August 2018 | Received in revised form 11 September 2018 | Accepted 25 September $2018 \mid$ Published online 1 October 2018 
activities such as chatting or playing with friends. In addition, there are still many students who do not want to ask questions when the teacher provides an opportunity to ask questions or express their opinions. So that the learning outcomes sometimes do not reach the KKM.

From the results of interviews with class II teachers, it is known that students have a low learning interest. Students lack enthusiasm and conflict when participating in the learning process. But to realize student-centered learning is also very difficult because of the background of students. As-Shakireen is a new school that was founded in 2015, so it still has grades 1 to 3 only. While classes 2 and 3, which are the first generation, some are students who have not been allowed to study in the previous school. Although class 1 down already has a lot of students. So that the background makes it difficult for teachers to realize student-centered learning.

Based on this problem, the alternative solution that can be done is to change the learning method that is more interesting to students and can gather the attention of students. One method that can be used is Demonstration. This method is chosen by adjusting the condition of students and for discussion with the class teacher. Still used Preaching method adjusts to the background and circumstances of students.

Demonstration method is a method of teaching by demonstrating goods, events, rules, and the sequence of doing activities, either directly or through the use of teaching media that are relevant to the subject matter or material being presented (Wahono, et.al., 2017).

The demonstration method is a method of presenting the lesson by demonstrating and demonstrating to students about a particular process, sequence, situation or object, either actually or just an imitation. As a method of presentation, demonstrations are not separated from verbal explanation by the teacher. The method of demonstration is to show, work on, and explain. That is, in the demonstration, we show and explain the ways of doing things.

Interest is one of the determining factors in the success of education. The impact of an interest in learning can foster new methods of learning students. Learning is said to be successful if it can foster attitudes, behavior, and ways of thinking in solving the problems faced. A student will succeed in the lesson if there is a desire to learn in the student. Interest will be formed if there is an effort from within him and there is also an external encouragement from both the teacher, family and environment to like and pay attention to physics lessons and the terminology of working on the questions given by the teacher (Astuti, 2015). Understanding of interest according to language (Etymology), is effort and willingness to learn and look for something. In terminology, interest is desire, liking, and willingness to something.

Motivation relates to results. Like if someone wants to win in a race, then he will always practice diligently so that the victory in the race he will follow. Thus, the motivation affects the activity. In connection with that, there are three motivational functions: 1) Encouraging people to do things; 2) determine the direction of action; 3) selecting actions. Apart from that, motivation can also encourage achievement. The existence of good motivation in learning will show good results.

Student learning outcomes can be used as a measure of learning success (Purwatiningsih, 2013). The level of students' understanding of the material that has been taught can be seen from the results of student learning (Nurcholish, 2013). According to Sunal in (Susanto, 2013: 5), "Evaluation is the process of using the information to make a judgment of how effective a program has met the needs of students. In addition, the evaluation or assessment can be used as feedback, or even a way to measure students' mastery level.

\section{METHODS}

The study took place in AugustSeptember 2018 at As-Shakireen Primary School, Waeng District, Thailand. The subjects of this study were all class II students in As-Shakireen Primary School, totaling 22 students with details of 14 male students and 8 female students.

This research is included in classroom action research (classroom action research). This research was carried out in accordance with the Hopkins model research design which was preceded by a preliminary action then continued with planning, action, observation, and reflection. The implementation of this study consists Data collection techniques used during the study were observations, interest scales, and tests. Observations that aim to observe the learning activities carried out by the teacher and students in the classroom, a scale to measure student

\section{Bioedukasi Vol. XVI. No. 2 Oktober 2018}


learning interest, and tests to determine the success of learning outcomes.

The instrument used to obtain teacher activity data and student activity using an observation sheet. The instrument used to find out the interest in learning using the interest scale. The instrument used to determine student learning outcomes is a test of learning outcomes. The success criteria in the study were $75 \%$ of class II students achieving learning interests and results with an average indicator of student scores with a minimum of good categories of 60 .

\section{RESULTS AND DISCUSSION}

This study was conducted to determine the effect of the demonstration method on learning interest and learning outcomes of class II students at As-Shakireen School. Learning activities take place well and in accordance with the lesson plan that has been made by researchers.

The results of observations carried out based on aspects of interest in learning are used to support the results of the study. Student learning interest can be known by using instruments in the form of interest scales that have been validated and then used for data retrieval. The scale of interest is in the form of observation data conducted by observers.

Interest scale with a range of $1-5$. With the following categories

$$
\begin{aligned}
& 1=\text { more than less } \\
& 2=\text { less } \\
& 3=\text { enough } \\
& 4=\text { good } \\
& 5=\text { very good }
\end{aligned}
$$

This table shows a comparison average of the scale of student learning interest. (Table 1.1)

\begin{tabular}{|l|l|l|l|}
\hline \multirow{2}{*}{ No. } & \multirow{2}{*}{$\begin{array}{c}\text { Observed } \\
\text { aspect }\end{array}$} & \multicolumn{2}{|c|}{ Interest value scale } \\
\cline { 3 - 4 } & Precycle & Cycle I \\
\hline 1 & Cution & 4 & 5 \\
\hline 2 & Enthusiastic & 2 & 5 \\
\hline 3 & Persist & 3 & 3 \\
\hline 4 & $\begin{array}{l}\text { Student } \\
\text { participation }\end{array}$ & 4 & 4 \\
\hline 5 & Curiosity & 2 & 3 \\
\hline Total & 16 & 20 \\
\hline \multicolumn{2}{|l}{ Percentage } & $64 \%$ & $80 \%$ \\
\hline
\end{tabular}

There was an interest scale that was assessed by the observer in the pre-cycle with a percentage of $64 \%$. While the scale of student interest in cycle 1 increased to $80 \%$. Based on these results, it can be described that the achievement of students' interest in all indicators is in a good category. This has proven that the application of the demonstration method in English learning can increase students' interest in learning.

Based on the table above it can be seen that students' interest in learning after applying the demonstration method increases. The average percentage at pre-cycle is $64 \%$ with enough categories, in cycle I $80 \%$ with good categories. Thus, the indicator of the success of learning interest has been achieved

From the results of the interest scale, it appears that there is an increase in the scale of interest in several aspects. Especially on the enthusiastic aspect, from a scale of 2 to 5 . The enthusiasm of students in pre-is very low because students look bored, then with this action becomes very increased. The aspect that does not experience improvement is the diligent aspect, the indicator of diligence is when working on the evaluation test questions given by the teacher. There are still some of the same students who do not solve the problem with the time specified.

English learning outcomes are measured by evaluation test questions done by students. Evaluation is given at the end of the cycle.

This table shows a comparison of mean values. (Table 1.2)

\begin{tabular}{|l|l|l|}
\hline Aspect & Precycle & Cycle 1 \\
\hline Average & 54 & 63 \\
\hline
\end{tabular}

Comparison of the average value shows in a diagram. (Diagram 1.1)

\section{Average of Learning outcomes}

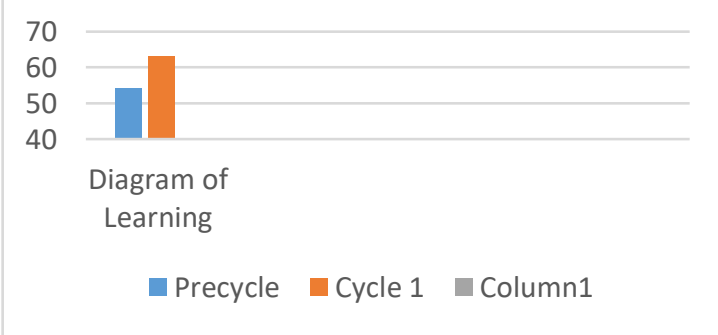

Based on the results of the study with an indicator of the average value of students, it can be seen that there is an increase from precycle after the action the average value of students increased too (54 to 63). From the data taken, there were also differences in the number of

\section{Bioedukasi Vol. XVI. No. 2 Oktober 2018}


students who completed the minimum criteria (60 students).

The learning actions by the researcher have been carried out well and in accordance with the objectives because students' learning interests and student learning outcomes indicate an increase. Based on the data and indicators used in Class II English subjects at As-Shakireen School, the Demonstration method can increase student interest and learning outcomes.

\section{CONCLUSION}

Based on the results of data analysis and discussion, increasing interest and learning outcomes in English is shown by the increasing value of interest scale and the average value of student learning outcomes. Based on the scale of interest in pre-cycle is $64 \%$, after the action is implemented it increases to $80 \%$. While student learning outcomes are indicated by the average value of students at pre-action is 54 after the action becomes 63 . So it can be concluded that the demonstration method has a positive influence on the interest and learning outcomes of grade II students in As-Shakireen Primary School.

\section{Acknowledgment}

With all respect and humility, writers praise the presence of Allah SWT for all His grace, so that the writers can finish this article. In making this article, the author's team gained valuable guidance, assistance, and guidance from various parties. On this occasion, the team of authors would like to extend their gratitude to Kamalia Fikri, S.Pd., M.Pd., Ulyanada, Official of UPPL FKIP Universitas Jember and AsShakireen school where this research was conducted, who have taken the time and opportunity to give opportunity, direction, and guidance in completion of this article.

\section{REFERENCES}

Astuti, Siwi Puji. 2015. Pengaruh Kemampuan Awal dan Minat Belajar terhadap Prestasi Belajar Fisika. Jurnal Formatif 5(1): 68-75.

Nurcholis. (2013). Implementation of Guided Discovery Methods to Improve Student Learning Outcomes. Tadulako Educational Journal, Vol. 1 (1), 32-42.

Purwatiningsi, S. (2013). Application of Guided Discovery Method to Increase Student Learning Outcomes on a material surface area and beam volume. Journal of Electronic Education and Mathematics Tadulako, Vol. 1 (1), 53-63.

Riswani \& Widayati. 2015. Active Learning Model with Learning Starts with a Question Technique in Increasing Student Activity in Accounting Learning Class XI Social Sciences 1 Yogyakarta 7 State High School. Indonesian Journal of Accounting Education. 10 (2): 1-8.

Siagian, F. Flora. 2015. Effect of Students' Interests and Learning Habits on Mathematics Learning Achievement. Formative Journal Vol. 2 (2): 122-131

Slameto. 2010. Belajar dan Faktor-faktor yang Mempengaruhinya. Jakarta: Rhineka Cipta.

Susanto, Ahmad. 2013. Teori Belajar dan Pembelajaran Edisi Pertama. Jakarta: Prenadamedia Gruop.

Wahono, N. Sa'ada, and T. Kurniawati. 2017. Demonstration Method Approach to Growing Early Age Motorized Skills. Journal of Pedagogy, Vol. 3 (2): 198-211.

Bioedukasi Vol. XVI. No. 2 Oktober 2018 